\title{
Narcissism in Iranian auditing profession
}

\author{
Bahman Banimahd $^{\mathrm{a}}$, Zahra Dianati Dilami ${ }^{\mathrm{b}}$ and Mahsa Javanmard ${ }^{\mathrm{c}^{*}}$
}

${ }^{a}$ Department of Accounting, Islamic Azad University ,Karaj Branch, Karaj, Iran

${ }^{b}$ Department of Accounting, University of Economic Sciences, Tehran , Iran

${ }^{c}$ M.Sc. Student, Department of Accounting University of Economic Sciences, Tehran, Iran

\section{H R O N I C L E A B S T R A C T}

Article history:

Received January 10, 2013

Received in revised format

8April 2013

Accepted 9 April 2013

Available online

April 102013

Keywords:

Narcissism

Audit market competition and

Auditor

\begin{abstract}
This study investigates the level of Narcissism among 185 Iranian auditors groups and narcissism has been used to describe people behavior in people groups. The present study uses a questionnaire to measure Narcissism and to examine the hypotheses of the paper analysis of variance and T-test are used. The results of testing hypotheses show that the level of narcissism was significantly different in auditors groups in private sector. However, in public sector, the difference between narcissistic personality in auditors' groups is not significant. Results of the study also indicated that, in private sector, narcissistic personality in young generation of auditors was higher than audit old generation. These results confirm previous studies on narcissism indicating that narcissistic behavior was high among young generation. We suggest the Iranian association of certified public accountants (IACPA) to review the ethical training needs for auditors. In addition, audit firms can provide a system to increase interaction among old generations of auditors with young generation of auditors.
\end{abstract}

\section{Introduction}

Narcissism has been used to explain behavior in organizations. Recent studies in finance, accounting and auditing texts indicate that narcissism describes firm manager's behavior. Narcissism is a relatively stable individual difference consisting of grandiosity, self-love and inflated self-views (Campbell et al. 2011). Accounting profession is a decision making discipline and all senior managers have to make decisions based on accountants and auditor's reports. Narcissistic personality motivations in auditors may influence on their decision making and judgment. When an auditor has a high level of narcissism, this may reflect on his/her auditing judgment about management performance and may result an overstated and biased reporting of firm performance. Many studies in accounting context, e.g. Cohen et al., 2010, have indicated that narcissism had a positive relation with behaviors in recent major frauds and scandals.

*Corresponding author. Tel: +989127049148

E-mail addresses: m_javanmard67@yahoo.com (M. Javanmard) 
According to Schrand and Zechman (2012), overconfident executives are more likely to exhibit an optimistic bias and thus are more likely to misreport. Our study investigates auditor's narcissism by examining the level of narcissism in private and public sectors of auditing profession. The importance of this study helps us have a better understanding about Iranian auditors' personality in a new and emerging audit market such as Iranian audit market. We select Iranian auditors because last studies on narcissism suggested that narcissistic behavior was high among young generation (Bergman et al., 2010). Iranian audit market, as an emerging audit market, was established in 2001. The evidence shows this market is engaged with more young auditors. Lack of sufficient studies about ethical subjects in Iranian accounting profession as well as competition in Iranian audit market have created a motivation for authors to conduct this study.

The main objective of this study is to recognize the level of narcissism in Iranian accounting profession. The other objective is to introduce narcissism as an unethical behavior in accounting climate, which could influence on audit opinion. It is important to point that this study provides some research results on overconfidence because narcissism and overconfidence are two related concepts and covered each other in different studies (Johnson et al., 2013).

This study contributes to the accounting literatures as follows: First, the result of this study can enhance the theoretical fundamentals of last studies on behavioral accounting research in developing countries. In addition, the results suggest that narcissism can be a behavioral and ethical risk factor in accounting profession. Finally, accounting oversight boards will be aware about narcissism as a fraud attitude, and this may motivate to monitor certified public accountants. In the following, literature review, research methodology and hypothesis testing are investigated.

\section{Literature review}

Recent studies in accounting suggest that narcissistic behavior likely expand fraud risk. Johnson et al. (2013) investigated whether auditors viewed narcissistic client behavior as a fraud risk. They showed that narcissism and fraud incentive were significantly and positively associated with auditors' overall fraud risk assessments. Huang and Kisgen (2013) studied relationship between gender and corporate finance and investment decision making. Their results indicated that women could make different decision on corporate finance and investment decision. They showed that firms with female managers were less likely to issue debt and make acquisitions than firms with male managers. Their results confirmed that men were overconfident compared with women.

Claussen et al. (2012) studied overconfidence between decision makers involved in monetary policy decisions. They prepared a theory on the decision structure in modern central banks. This theory described that people were not perfect information aggregators and in particular that they were subject to overconfidence. They found that overconfidence implies that flat structures of information transmission within the central bank staff were superior to hierarchical structures in terms of the quality of advice reaching the bank's chair.

Lambert et al. (2012) indicated that there was no difference between bankers and students in the degree of overconfidence. They also concluded that overconfidence could determine decision-making in a different way between the two groups. Their results among students indicated overconfidence impact on general tasks such as assets valuation and risk aversion. They also reported overconfidence impact on specific tasks such as valuation and investment choices among bank staffs. Brunell et al. (2011) believed that narcissism could lead to unethical behaviors to obtain greater rewards by managers.

Han et al. (2011) suggested that audit anagers' (seniors') overconfidence in audit seniors' (managers') technical knowledge was larger (smaller) for a more difficult task than for a less difficult task, for 
both individual and group predictions. Chatterjee and Hambrick (2011) suggested when Chief Executive Officer (CEO) narcissism is high, CEO tends to show an increase in firm financial performance, and they are less responsive to negative firm performance. Amernic et al. (2010) indicated that executive narcissism with less-effective corporate governance can increase organizational misconduct.

Bergman et al. (2010) indicated that narcissism levels had increased among American business students in 25-year period. They suggested instructors must teach effectively and monitor students' behavior. They concluded that increase in narcissism among business students may be raised by a combination of parenting style and societal conditions. They suggested that students motivated by their parents and their society to consider themselves better than others.

Chuang and Lee (2006) provided some evidence on the existence of overconfidence in capital markets. They showed that overconfident investors react to private information. Capital market also gains make overconfident investors in next periods and overconfident investors lower risk and trade more in risky stocks. Penney and Spector (2002) showed that narcissism reduce the relationship between organizational constraints and business work behavior. They suggested that those high on narcissism were more reactive to the environment and concluded that narcissism was a filter of organizational constraints.

\section{Research methodology}

\subsection{Participants}

The participants were 186 Iranian public accountants have employed by Audit Organization (A governmental audit firm) and private audit firms. There were 44 females, and 142 males, 119 worked in audit organization and 67 worked in private audit firms. The accountants were selected randomly from state and private audit firms .

\subsection{Procedure}

Narcissism was measured by using a version of The Narcissistic Personality Inventory (Raskin \& Hall, 1979), a 40 items self-report questionnaire developed for nonclinical populations. Respondents answered "true" or "false" for each of the 40 items. We have used Analysis of Variance and T- test for the testing of hypotheses.

\section{Research Hypotheses}

Given theoretical fundamentals and literature review, the following hypotheses are stated for this study :

Hypothesis 1: The Mean of Narcissism is equal in different Job grades in Audit organization.

Hypothesis 2: The Mean of Narcissism is equal in different Job grades in private audit firms.

Hypothesis 3: The Mean of Narcissism is equal in state and private audit firms.

Hypothesis 4: The Mean of Narcissism is equal in female and male. 


\section{Results}

Table 1 shows descriptive statistics of the study and indicates that mean of narcissism between two groups of accountants in audit organization and private audit firms is equal and has not a significant variation.

\section{Table 1}

Descriptive statistics of the study

\begin{tabular}{lcccrr}
\hline & Mean & Median & STD & Max & Min \\
\hline Audit Organization & 20.18 & 20.000 & 4.18 & 30 & 6 \\
Private Audit Firms & 20.35 & 21.000 & 3.62 & 30 & 15 \\
\hline
\end{tabular}

Table 2 also indicated that the mean of narcissism in different rank of jobs in audit organization are almost equal, but in private audit firms are not equal.

Table 2

Descriptive statistics of the study

\begin{tabular}{lcccccc}
\hline Job Grades & \multicolumn{3}{c}{ Private Audit Firms } & \multicolumn{3}{c}{ Audit organization } \\
\cline { 2 - 7 } & $\mathrm{N}$ & Mean & STD & N & Mean & STD \\
\hline Auditor & 25 & 21.04 & 3.49 & 20 & 20.65 & 4.12 \\
Senior Auditor & 14 & 22.57 & 4.35 & 26 & 20.69 & 3.87 \\
Audit Supervisor & 15 & 17.75 & 2.63 & 39 & 19.90 & 4.98 \\
Audit Manger & 13 & 17.33 & 3.21 & 34 & 19.85 & 3.50 \\
\hline
\end{tabular}

Table 3 shows the results of Kolmogorov-Smirnov test and reveal that the distribution of the study sample is normal. Table 4 also shows hypotheses testing.

Table 3

Kolmogorov-Smirnov test

\begin{tabular}{lll}
\hline Variable & Kolmogorov-Smirnov Z & P- Value \\
\hline Narcissism & 1.090 & 0.196 \\
\hline
\end{tabular}

Table 4 demonstrates the summary of testing four hypotheses of this paper.

\section{Table 4}

Hypotheses Testing

\begin{tabular}{|c|c|c|c|c|}
\hline Hypotheses & \multicolumn{2}{|c|}{ Statistics } & P-Value & Results \\
\hline $\begin{array}{l}\text { The Mean of Narcissism is equal in different } \\
\text { Job grades in Audit organization. }\end{array}$ & $\begin{array}{l}\text { Analysis of } \\
\text { Variance }\end{array}$ & $\mathrm{F}=0.34$ & 0.798 & $\begin{array}{l}\text { The hypothesis is } \\
\text { confirmed }\end{array}$ \\
\hline $\begin{array}{l}\text { The Mean of Narcissism is equal in different } \\
\text { Job grades in private audit firms }\end{array}$ & $\begin{array}{l}\text { Analysis of } \\
\text { Variance }\end{array}$ & $\mathrm{F}=2.83$ & 0.042 & $\begin{array}{l}\text { The hypothesis is } \\
\text { rejected }\end{array}$ \\
\hline $\begin{array}{l}\text { The Mean of Narcissism is equal in state and } \\
\text { private audit firms. }\end{array}$ & $\mathrm{T}$ - test & $\mathrm{T}=-1.11$ & 0.268 & $\begin{array}{l}\text { The hypothesis is } \\
\text { confirmed }\end{array}$ \\
\hline $\begin{array}{l}\text { The Mean of Narcissism is equal in female } \\
\text { and male. }\end{array}$ & T- test & $\mathrm{T}=1.30$ & 0.196 & $\begin{array}{l}\text { The hypothesis is } \\
\text { confirmed }\end{array}$ \\
\hline
\end{tabular}

\section{Concluding Remarks}

In this study, we assess narcissism on Iranian audit profession and the results of this study have indicated that level of narcissism was significantly different in audit job levels in private sector. However, in public sector, the difference between narcissistic personalities in audit job grades was 
very low and was not significant. We can see narcissistic personality among auditors and senior auditors (young generation) is higher than audit supervisor and audit manager (old generation) in private sector based on some descriptive statistics. These results are consistent with previous studies on narcissism, which indicated narcissistic behavior was higher in young generation such as Bergman et al. (2010).

We have extended literatures by providing the first empirical evidence on Iranian on auditors' narcissism. This evidence indicated that level of narcissism was different in auditor groups especially in private sector. This finding is important for audit firms to manage auditors groups particularly auditors and senior auditors. We provide evidence that competition in Iranian audit market can increase narcissistic personality in groups of auditors. On the basis of the results, we suggest that the Iranian association of certified public accountants (IACPA) review the ethical training needs for auditors. IACPA can manage and train management styles in audit firms. Audit firms also can provide a plan or system to increase audit supervisor and audit manager interaction with auditors and senior auditors. We have not investigated influences of the societal norms on the auditors' narcissism, hence, we suggest evaluating factors influencing of the auditors' narcissism on the basis of the social norms perspective in future studies.

\section{References}

Amernic, J., Craig, R. \& Tourish, D. ( 2010) Measuring and Assessing Tone at the Top Using Annual Report CEO Letters. Edinburgh, Scotland: The Institute of Chartered Accountants of Scotland. 1-30.

Bergman, J. Z. Westerman , J, W, \& Daly, J, P. (2010) Narcissism in Management Education, Academy of Management Learning \& Education, Vol. 9, No. 1, 119-131.

Brunell, A. B., Staats, S., Barden, J., \& Hupp, J.M. (2011) Narcissism and academic dishonesty: The exhibitionism dimension and the lack of guilt. Personality and Individual Differences 50 (3), 323 328.

Campbell, W. K., Hoffman, B.J., Campbell, S. M., \& Marchisio, G. (2011). Narcissism in organizational contexts, Human Resource Management Review 21 , 268-284

Chatterjee, A., \& Hambrick. D. C. (2011) Executive personality, capability cues, and risk taking: How narcissistic CEOs react to their successes and stumbles. Administrative Science Quarterly 56 (2), 202-237.

Claussen, C.A., Matsen, E., Roisland, O., \& Torvik, R. (2012). Overconfidence, monetary policy committees and chairman dominance, Journal of Economic Behavior \& Organization 81 , 699711.

Cohen, J. Y., Lesage, D. C., \& Stolowy, H. ( 2010) Corporate fraud and managers' behavior: Evidence from the press. Journal of Business Ethics 95 (Supplement 2), 271-315.

Chuang, W.I. \& Lee, B.S. (2006) An empirical evaluation of the overconfidence hypothesis. Journal of Banking \& Finance, 30, 2489-2515.

Johnson, E. N., Kuhn, J. R., Barbara A., Apostolou, Jr., \& Hassell, J. M. (2013) Auditor Perceptions of Client Narcissism as a Fraud Attitude Risk Factor. Auditing: A Journal of Practice \& Theory, 32(1), 203-219.

Han, J., Karim, J., \& Tan, H. (2011). Auditors' Overconfidence in Predicting the Technical Knowledge of Superiors and Subordinates, Auditing: A Journal of Practice \&Theory, 30(1), 101119.

Huang, J., \& Kisgen, D. (2013). Gender and corporate finance: Are male executives overconfident relative to female executives? Forthcoming in Journal of Financial Economics

Lambert, J., Bessière, V., \& N'Goala, G. (2012). Does expertise influence the impact of overconfidence on judgment, valuation and investment decision? Journal of Economic Psychology 33, 1115-1128. 
1426

Penney, L. M., \& Spector, P. E. (2002). Narcissism and counterproductive work behavior: Do bigger egos mean bigger problems? International Journal of Selection and Assessment, 10, 126-134.

Raskin, R., \& Hall, C. S. (1979). A narcissistic personality inventory. Psychological Reports, 45, 590.

Schrand, C. M., \& Zechman, S. L. C. ( 2012) Executive overconfidence and the slippery slope to financial misreporting. Journal of Accounting and Economics, 53(1-2), 311-329. 